Onomastica Slavogermanica

XXXI

Wrocław 2019

DOI: $10.19195 / 0474-1471.31 .4$

IRYNA PROTSYK

Kijów

\title{
Nazwy ukraińskich klubów piłkarskich w Galicji w pierwszej połowie XX wieku
}

Słowa kluczowe: chrematonimia, nazwy klubów galicyjskich, źródła nominacji

Na początku XX wieku w Galicji aktywnie rozwijał się ruch sportowy. Powstały tu towarzystwa „Sokił” [,,Sokół”], „Sicz”, „,Luh” [„,Ląka”], „Płast”l promujące i rozpowszechniające informacje na temat różnych dyscyplin sportowych w ramach organizowania sekcji sportowych. Niemal każde towarzystwo sportowe w pierwszej kolejności zakładało sekcję piłki nożnej², czyli kopanej³ jak ją wtedy nazywano. Ukraińskie organizacje sportowe zajmowały się popularyzacją tej dyscypliny sportu i tworzeniem drużyn piłkarskich zarówno w dużych miastach, jak i w małych miasteczkach, na wsiach.

Przedmiotem moich badań są nazwy ukraińskich klubów piłkarskich w Galicji pierwszej połowy XX wieku oraz prześledzenie uwarunkowań ich nadawania. Jako podstawowe źródło badawcze wykorzystałam materiał z czasopism o tematyce sportowej funkcjonujących w Galicji w okresie międzywojennym w latach 20-30. XX wieku. Materiały pochodzą głównie z magazynów: „Sport. Magazyn dedykowany wszystkim sportom” (1925-1926), „Wiadomości sportowe. Tygodnik Ilustrowany” (1931, 1933), tygodnika „Gotowe. Magazyn Ukraińskiej Spółki Sportowej” (1934-1935), dwutygodnika „Sport. Magazyn Ukraińskiej Spółki Sportowej” (1936-1937), „Zmah [Rywalizacja]. Tygodnik sportowy” (1937-1939), a także ze stron sportowych w periodykach niespecjalistycznych, w tym: „Ruchankowo-sportowy wistnyk” [„Kurier gimnastyczno-sportowy”] — dodatek do czasopisma studenckiego „Postup” [„Postęp”] (1922-1923), dodatek dwutygodniowy do czasopisma „Nowy Czas” „Ruchanka i Sport” [„Gimnasty-

${ }^{1}$ І. Андрухів, Украӥнські молодіжні товариства Галичини 1861-1939 рр., Івано-Франківськ 1995, s. 72.

${ }^{2}$ I. Боберський, Забави і гри рухові, ч. III. Копаний мяч, Львів 1906, s. 36; Верхола О. Копаний мяч, Львів 1926, s. 90.

3 В. Лаврівський, Копана (Association Football), Львів 1900, s. 18.

ONOMASTICA SLAVOGERMANICA

XXXI, 2019

(C) for this edition by CNS 
ka i Sport”] (1926), dodatek do czasopisma „Nowy Czas” „Ruchanka i Sport” [„,Gimnastyka i Sport”] (1928), dodatek tygodniowy do czasopisma „Nowy Czas” „Sport” (1931) będący oficjalną stroną Ukraińskiej Spółki Sportowej, dodatek miesięczny do czasopisma dla młodzieży „Vohni” [„Ognie”] „Sport i młodzież” (1931-1934) pod redakcją Ukraińskiej Spółki Sportowej oraz dodatek „Wychowanie fizyczne” umieszczony w dwutygodniku „Szlah molodi” [„Droga młodzieży"] (1939).

W wieloetnicznej Galicji stowarzyszenia sportowe tworzono na podstawie narodowości - istniały kluby polskie, ukraińskie, żydowskie. Dlatego też w nazwach klubów i towarzystw galicyjskich odzwierciedlono kryterium narodowościowe. Nazwę drużyny zawsze poprzedzała wskazówka o narodowości, na przykład U.S.K. - Ukraiński Klub Sportowy (w języku ukraińskim szyk odwrotny - Sportowyj Klub), U.S.T. - Ukraińskie Towarzystwo Sportowe, P.K.S. — Polski Klub Sportowy, Ż.K.S. — Żydowski Klub Sportowy. Czasami pierwszy element tego typu skrótów to nazwa miejscowości, z której pochodzi drużyna piłkarska, na przykład L.K.S. - Lwowski Klub Sportowy. Przy nazwach wiejskich towarzystw sportowych, będących jedynymi tego typu organizacjami, nie zaznaczano narodowości, używano jedynie skrótu S.K. - Klub Sportowy lub S.T. - Towarzystwo Sportowe; komponent narodowy wykorzystano w nazwie Towarzystwa Sportowego „Ukraina” (Lwów) - S.T. Ukraina4; kilka stowarzyszeń sportowych używało akronimów: U.R.S.K. — Ukraińskie Robotnicze Koło Sportowe i U.S.S.K. - Ukraiński Sportowy Klub Studencki.

Złożona struktura nazw drużyn piłkarskich była tworzona przez łączenie składnika, którym jest skrót (powstały na skutek oszczędności językowej) wraz z nazwą własną. Drugi składnik tej nazwy złożonej motywowany jest nazwą własną lub rzeczownikiem ogólnym. Nazwy większości klubów piłkarskich Galicji odzwierciedlają ich stałe odniesienie do realiów historycznych, kulturowych i społecznych Ukrainy. Nazwy własne ukraińskich drużyn piłkarskich z Galicji zawierają ważne dla Ukraińców konotacje, składniki kultury ukraińskiej — zarówno pozytywne, jak i negatywne.

Analizując nazwy własne, należy prześledzić szczególne uwarunkowania leżące u podstaw nadawania nazw różnym klubom piłkarskim. Wiele klubów stosowało w tytule nazwę swojego miasta, miasteczka, wsi lub nazwę regionu, w którym klub funkcjonował, czyli toponimy, na przykład: U.S.K. Dobromyl — od nazwy miasta Dobromyl ${ }^{5}$ w rejonie starosamborskim, obwód lwowski; S.K. Dobriany — od nazwy wsi Dobriany ${ }^{6}$ rejonu stryjskiego, obwód lwowski; U.R.S.K. Kołomyja — od nazwy miasta rejonowego obwodu iwano-frankowskie-

4 Спортове Товариство „Украӥна” (Львів). До 80-річчя заснування: Альманах, red. Й. Лось et al., Львів 1991, s. 136.

5 М.П. Янко, Топонімічний словник України: Словник-довідник, Київ 1998, s. 122.

6 Zob./wiki/Dobriany,_Stryi_Raion (dostęp: 2.07.2016). 
go $^{7}$ - Kołomyja ${ }^{8}$; S.K. Załużżia ${ }^{9}$ — od nazwy miejscowości Załuże w rejonie rohatyńskim, obwód iwano-frankowski; S.K. Pawełcze — od nazwy wsi Paweł$\mathrm{cze}^{10}$ lub Pawełcza rejonu tyśmienickiego, obwodu iwano-frankowskiego, aktualna nazwa - Pawliwka; U.S.K. Stanisławiw — od nazwy miasta Stanisławów ${ }^{11}$, S.K. Toporiwci - od nazwy wsi Toporiwci ${ }^{12}$ rejonu horodenkowskiego, obwód iwano-frankowski; U.S.T. Chodoriw — od nazwy miasta Chodorów ${ }^{13}$ rejonu żydaczowskiego, obwód lwowski; S.K. Czerczanka — od nazwy wsi Czercze ${ }^{14}$ rejonu rohatyńskiego, obwód iwano-frankowski; U.S.K. Jamnycia — od nazwy miejscowości Jamnica ${ }^{15}$ koło Iwano-Frankowska.

Nazwy etnicznych regionów Ukrainy — Podilla [Podole] i Pidhirya [Podgórze] - wykorzystano w nazwach galicyjskich drużyn piłkarskich z Tarnopola oraz Drohobycza reprezentujących odpowiednio te dwa regiony: U.S.T. Podilla (Tarnopol) i U.S.T. Pidhirya (Drohobycz).

W nazwach drużyn piłkarskich wskazuje się na konkretne cechy obszarów, nazwy mieszkańców albo rodzaj ich zawodu. Na przykład zespół z Sanoka, który należy do etnograficznego regionu Łemkowszczyna, używa nazwy mieszkańców tego regionu — Łemky — U.S.K. Łemko. Borysławski zespół piłkarski w swojej nazwie U.S.T. Ropnyk podkreślił dominujące zajęcie mieszkańców przemysłowego regionu Galicji na przełomie XIX-XX w., czyli pozyskiwanie ropy naftowej; zespół U.S.K. Kameniari [Kamieniarze] ze wsi Serafynci koło Horodenki oraz drużyna z miejscowości Wowczyniec w pobliżu Iwano-Frankowska w nazwie odzwierciedliły rozwinięte tutaj rzemiosło - wydobywanie kamienia.

Oprócz nazw miejscowości, w których powstały i funkcjonowały kluby piłki nożnej, nazwy drużyn często wskazują nazwy miejscowości ważne dla ukraińskiej świadomości narodowej i wykazują ciągłość pamięci historycznej i tradycji kulturalnej, w tym: U.S.K. Baturyn (Przemyśl) - nazwa stolicy hetmana Iwana Mazepy, miasta Baturyn ${ }^{16}$ położonego w powiecie bachmackim obwodu czernihowskiego.

Na podstawie nazwy „Sicz Zaporoska”17, oznaczającej organizację społeczno-polityczną i wojskowo-administracyjną ukraińskich Kozaków, znajdującą się w południowej części Ukrainy, ,za porohami Dniepru” (czyli za szczególnym ro-

7 Obecna nazwa byłego województwa stanisławowskiego, ponieważ w roku 1962 nazwa miasta Stanisławów została zmieniona na Iwano-Frankiwsk.

8 М.П. Янко, op. cit., s. 183.

9 Zob./wiki/Rohatyn_Raion (dostęp: 2.07.2016).

10 Ibidem.

11 Obecna nazwa „Iwano-Frankowsk” (fonetycznie z języka ukraińskiego — Iwano-Frankiwsk; transkrypcja międzynarodowa oparta na transliteracji angielskiej — Ivano-Frankivsk).

12 Ibidem.

13 М.П. Янко, op. cit., s. 374.

14 Zob. wiki/Cherche (dostęp: 2.07.2016).

15 Ibidem.

16 М.П. Янко, op. cit., s. 35.

17 Ibidem, s. 142. 
dzajem wodospadów), utworzono nazwy kilku galicyjskich klubów piłkarskich: S.T. Sicz ze wsi Dobriany w rejonie stryjskim obwodu lwowskiego i S.K. Zaporożec z miasteczka Nyżankowyczi (Niżankowice) rejonu starosamborskiego obwodu lwowskiego. Nazwa lwowskiego klubu piłkarskiego U.S.K. Czornomorec [Czarnomorzec] też wywodzi się od historycznej wzmianki o Kozakach czarnomorskich.

Inny leksem, który tematycznie pasuje do przedstawionych nominacji, to nazwa geograficzna Chortycia ${ }^{18}$ - nazwa największej wyspy na Dnieprze (w pobliżu północnego jej brzegu znajdowały się ogromne progi rzeki będące we władaniu Siczy Zaporoskiej). Wykorzystano go do nazywania klubów piłkarskich U.S.T. Chortycia z miasta Borszczów obwodu tarnopolskiego, z miasta Żydaczów obwodu lwowskiego i z miasta Lubaczów (obecnie administracyjnie należy do województwa podkarpackiego w Polsce).

Liczną grupę nazw ukraińskich klubów piłkarskich tworzą nazwy motywowane onimami różnych obiektów geograficznych: mas wodnych — hydronimami, wzniesień i gór - oronimami itp. Spośród hydronimów do nominacji galicyjskich drużyn piłkarskich użyto przede wszystkim nazw własnych rzek, występujących na terenie, na którym został założony dany klub sportowy, na przykład U.S.K. Bystrycia z miasta Nadwórna położonego nad brzegiem Bystrzycy Nadwórniańskiej ${ }^{19}$, U.S.T. Prut z miasta Delatyn, w pobliżu którego płynie rzeka Prut ${ }^{20}$, U.S.K. Sian z Przemyśla leżącego na obu brzegach Sianu (Sanu) ${ }^{21}$, U.S.K. Wigor z miasteczka Niżankowice rejonu starosamborskiego, przez które przepływa rzeka Wigor ${ }^{22}$ - dopływ Sanu. Nadsańska drużyna piłkarska S.K. Zbrucz ze wsi Oleszyce w swojej nazwie wykorzystała hydronim, który był symbolem podziału Ukrainy przez granicę dwóch państw przebiegającą wzdłuż rzeki Zbrucz ${ }^{23}$. Dwa zespoły z obwodu lwowskiego odzwierciedliły w swoich nazwach ich bliskość terytorialną do największej rzeki regionu — Dniestru24: U.S.T. Dniestr z Sambora i U.S.T. Dniestr z Mikołajowa. Drużyna z miasteczka Winniki koło Lwowa oraz Wysokoszkolny Ukraiński Klub Sportowy z Podiebradów w Republice Czeskiej, gdzie licznie zamieszkali emigranci z Ukrainy po klęsce walk z lat 1918-1921, mają w swoim tytule hydronim Dniepr ${ }^{25}$ — nazwę największej ukraińskiej rzeki (U.S.K. Dnipro).

Wśród oronimów wykorzystanych w nominacjach galicyjskich drużyn piłkarskich warto wymienić: U.S.K. Łysonia (Bereżany, Brzeżany) pochodzi od na-

18 М.П. Янко, ор. cit., s. 376.

19 Словник гідронімів Украӥни, red. А.П. Непокупний, О.С. Стрижак, К.К. Цілуйко, Київ 1979, s. 50.

20 Ibidem, s. 451.

21 Ibidem, s. 551.

22 Ibidem, s. 106.

23 Ibidem, s. 209.

24 Ibidem, s. 173-174.

25 Ibidem, s. 173. 
zwy góry Łysonia ${ }^{26}$ w pobliżu miasta Brzeżany; S.T. Czarnogóra (Stanisławów) pochodzi od nazwy Czarnogóra ${ }^{27}$ — najwyższego grzbietu Karpat Ukraińskich; S.K. Howerla (Stanisławów) pochodzi od nazwy najwyższego szczytu Karpat — góry Howerla ${ }^{28}$ wznoszącej się w pasmie górskim Czarnogóra. Nazwy obu drużyn sportowych Stanisławowa (obecnie Iwano-Frankowsk) - największego miasta $\mathrm{w}$ tym górzystym regionie - motywacyjnie związane są z oronimami Karpat.

Dwa zespoły z obszarów położonych w Karpatach Ukraińskich wykorzystały w nazwie leksem beskyd (góra, skała ${ }^{29}$ ) używany na określenie systemu pasm górskich w północnej strefie Karpat ${ }^{30}$. Są to drużyny z miast Nadwórna w pobliżu Iwano-Frankowska oraz Turka w obwodzie lwowskim - U.S.T. Beskyd (Nadwórna), U.S.K. Beskyd (Turka). Ten sam onim, który nominuje potężny grzbiet Karpat, widać w nazwie klubu piłkarskiego ze wsi Probiżna rejonu Kopyczyńskiego pod Tarnopolem — S.K. Beskyd (Probiżna).

Tematycznie blisko tej grupy nazw tworzących bazę nazywania galicyjskich drużyn piłkarskich są nazwy apelatywne wskazujące cechy terenów górskich oraz nominujące obszary charakterystyczne dla Ukrainy: U.S.K. Skała (Stryj), U.S.K. Skała (Mościska) — pochodzi od starej nazwy zwyczajowej skała ${ }^{31}$; U.S.K. Step (Buszkowice) ze wsi Buszkowice pod Przemyślem — pochodzi od nazwy apelatywnej step — duża bezdrzewna, pokryta roślinnością trawiastą płaska powierzchnia w strefie klimatu suchego ${ }^{32}$, nazwy naturalnego obszaru w umiarkowanych szerokościach geograficznych, obejmującego sporą część terytorium Ukrainy; S.T. Płaj (Lwów) — od dialektowego leksemu płaj, który oznacza spłaszczony grzbiet gór z pastwiskami i ścieżkami w Karpatach ${ }^{33}$.

Osobna grupa nazw, które stały się podstawą motywowania nominacji ukraińskich klubów piłkarskich, to antroponimy. Wśród nich są imiona, nazwiska znanych i ważnych dla Ukraińców postaci historycznych: Iwan Bohun, Oleksa Dowbusz, Ustym Karmeluk, Roksolana, Fedir Czernyk.

Nominacja klubu piłkarskiego U.S.K. Roksolana z Rohatyna jest w pełni uzasadniona, ponieważ legenda o Nastii Lisowskiej, która później została żoną osmańskiego sułtana Sulejmana Wspaniałego — Roksolaną, wiąże się z Rohatynem, jej rodzinnym miastem.

Wśród nazw klubów piłkarskich są też znane z historii nazwiska ukraińskich powstańców: Oleksy Dowbusza — lidera buntowników w Karpatach i Ustyma

26 Zob. /wiki/Berezhany (dostęp: 02.07.2016).

27 Ibidem.

28 Ibidem.

29 Великий тлумачний словник сучасної украӥнської мови, oprac. i red. В.Т. Бусел, Київ-Ірпінь 2001, s. 48.

30 Zob./wiki/Carpathian_Mountains (dostęp: 2.07.2016).

31 Великий тлумачний словник..., s. 1131.

32 Ibidem, s. 1193.

33 Ibidem, s. 76. 
Karmeluka — przywódcy rebeliantów na Podolu. Imienia pierwszego z nich użyła w swojej nazwie drużyna piłkarska z Kołomyi U.S.T. Dowbusz, a imienia drugiego — zespół piłkarski ze wsi Krówniki koło Przemyśla U.S.K. Karmeluk. Oprócz galicyjskich klubów nazwisko Oleksy Dowbusza znajduje również odzwierciedlenie w tytule bukowińskiego klubu - U.S.K. Dowbusz (Czerniowce).

Aż cztery galicyjskie centra sportowe do nazwania swoich klubów piłkarskich wykorzystały nazwisko przywódcy wojskowego i polityka z czasów Bohdana Chmielnickiego, dowódcy kozackiego wojska zaporoskiego Iwana Bohuna. Są to drużyny ze Lwowa (dzielnica Lewandówka), miast Brody i Komarno U.S.K. Bohun oraz wsi Serafynci koło Horodenki - S.K. Bohun.

Przezwisko księcia Rusi Wsiewołoda, syna Światosława, Buj-Tura, który prowadził armię $\mathrm{w}$ walce $\mathrm{z}$ Połowcami, wykorzystane było jako nazwa dwóch galicyjskich drużyn piłkarskich - Buj-Tur (Lwów, dzielnica Syhnówka), Buj-Tur (Stanisławów), jak również Ukraińskiego Bractwa Sportowego Tur (Praga, Republika Czeska).

Nazwa U.S.T. Czernik (Stanisławów) związana jest z najnowszą historią Ukrainy. Klub piłkarski wykorzystał ją na cześć Fedora Czernika ${ }^{34}$, skauta, setnika Legionu Ukraińskich Strzelców Siczowych, który zginął w bitwie pod Motowyłiwką w 1918 roku i został pochowany na mogile Askolda.

Istnieje też jeden antroponim z historii starożytnej, który stał się podstawą motywacyjną do nazwania ukraińskiego piłkarskiego kółka robotniczego U.R.S.K. Spartak (Przemyśl). Wśród galicyjskich klubów sportowych jedynie przemyski zespół używał nazwy, w której skład wchodziło imię wojownika trackiego Spartakusa, wodza zbuntowanych przeciwko Rzymianom niewolników (w przeciwieństwie do klubów sowieckiej Ukrainy, gdzie nominacja ta cieszyła się bardzo dużą popularnością).

Znaczną grupę nazw drużyn piłkarskich obejmują nominacje motywowane nazwami apelatywnymi, w tym w szczególności nazwy zjawisk naturalnych: S.K. Burewij (Lwów, dzielnica Lewandówka) i S.K. Burewij (Buczacz), S.K. Burewij (wieś Pasieczna koło Nadwórnej) — od leksemu burewij — bardzo silny wiatr, huragan ${ }^{35}$, nazwa potężnego i długo trwającego zjawiska atmosferycznego o mocy niszczącej; U.S.K. Zahrawa (Stanisławów) - od wyrazu zahrawa (poświata), co oznacza odbicie (głównie w niebie), jasne światło, ogień ${ }^{36}$, światło na niebie podczas wschodu lub zachodu słońca; S.K. Wychor (Jamnica) — od leksemu wychor (trąba powietrzna) - nazwy wiatru ${ }^{37}$ o szarpanym kołowym ruchu lub silnego wiatru porywistego; S.K. Churtowyna (Komarno) — od słowa churtowyna - silne wiatry i śnieg, zamieć ${ }^{38}$, nazwa zjawiska atmosferycznego,

\footnotetext{
34 Спортове Товариство „Україна” (Львів), s. 29.

35 Великий тлумачний словник..., s. 67.

36 Ibidem, s. 292.

37 Ibidem, s. 119.

38 Ibidem, s. 1356.
} 
którym jest przenoszenie śniegu przez wiatr nad ziemią i towarzyszące temu pogorszenie widoczności; S.K. Kometa (Lwów) - od terminu kometa, co oznacza ciało niebieskie z jasnym jądrem i mglistą powłoką, od której rozciąga się długie pasmo światła, przypominające ogon ${ }^{39}$; U.S.K. Zoria (Lwów), U.S.K. Zoria (Chodorów) - od leksemu zoria (gwiazda) oznaczającego świecące ciało niebieskie, czyli skupisko gorących gazów ${ }^{40}$.

Dość liczną, ale niezbyt zróżnicowaną grupę tworzą nominacje drużyn piłkarskich motywowane nazwami ptaków, mianowicie: sokół, orzeł i mewa. Ponad dwadzieścia klubów piłki nożnej w tytule użyło leksemu sokit [sokół], co jest całkiem naturalne, ponieważ najstarszym (od 1894 roku) oraz najmocniejszym ukraińskim stowarzyszeniem sportowym było Ruchankowe Sportowe Towarzystwo [Gimnastyczne Towarzystwo Sportowe] „Sokół” (od 1905 roku — „Sokół-Ojciec”), które łączyło w Galicji setki oddziałów i ponad dziesięć tysięcy członków ${ }^{41}$. Nazwę U.S.K. Sokił nosiły między innymi zespoły takich galicyjskich miast i wsi: Bóbrka, Gliniany, Drohobycz, Zawadów, Złoczów, Koniuchów, Krasne, Lwów, Nakonieczne I, Nakonieczne II, Skole, Stryj, Sądowa Wiśnia, Chodorów, Jaworów — w obwodzie lwowskim; Bohorodczany, Bodnarów, Kołomyja, Kuty, Otynia, Rohatyn, Stanisławów - w obwodzie iwano-frankowskim; Podhajce, Trzebowla, Wasylkowce (w pobliżu miasteczka Kopyczyńce) — w obwodzie tarnopolskim; Przemyśl. Nazwy stowarzyszenia sportowego i drużyn piłkarskich związane z leksemem sokit odnoszą się do drapieżnego ptaka $\mathrm{z}$ rodziny sokołowatych ${ }^{42}$ będącego symbolem odwagi, męskości i siły. Inna nazwa ptaka używana w nominowaniu galicyjskich drużyn piłkarskich to leksem czajka (mewa) — ptak morski z rodziny mewowatych $^{43}$. Chociaż jest to rzadki ptak w Galicji, zoonim ten obecny jest w nazwach zespołów z regionu Lwowa, Iwano-Frankowska i Tarnopola - U.S.K. Czajka (Kałusz), S.K. Czajka (Tołmacz), S.K. Czajka (Czortków). Wynika to prawdopodobnie z aktywnego używania tego leksemu w folklorze ukraińskim. Leksem berkut (orzeł przedni) - nazwę dużego ptaka drapieżnego z rodziny jastrzębiowatych ${ }^{44}$, który jest symbolem odwagi, wytrzymałości, siły - wykorzystano do nazwania drużyny piłkarskiej Przemyśla - U.S.K. Berkut.

Odrębna grupa leksemów wykorzystanych do mianowania klubów piłkarskich to leksemy semantycznie powiązane z nominowaniem pojęć ważnych dla Ukraińców jako narodowości, czyli powiązane z pojęciami „państwo”, „patriotyzm", symbolami państwowymi i narodowymi. Wśród nich są nazwy własne (Ukraina, Ruś) i nazwy ogólne (tryzub, jedność, kalyna [kalina]).

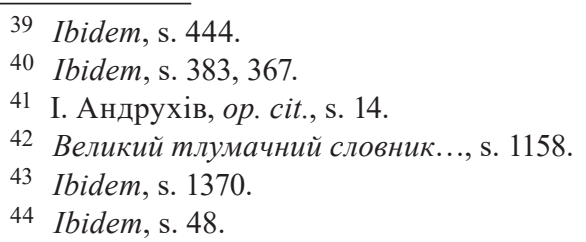


Towarzystwo Sportowe S.T. Ukraina (Lwów), jedno z największych i najpotężniejszych galicyjskich organizacji gimnastycznych i wychowawczych oraz drużyna piłkarska będąca w jego składzie, przyjęły nominację państwa Ukrainy, podkreślając narodową tożsamość sportowców w warunkach, gdy państwo nie istniało, co było wyrazem wielkiego patriotyzmu, odwagi i męstwa. Jak wspominał słynny w latach 30-40. XX wieku ukraiński piłkarz, a później emigrant polityczny Aleksander (Lenio) Skoceń, „S.T. Ukraina (Lwów) jest symbolem sportu ukraińskiego i ducha narodowego. [...] Sama nazwa towarzystwa była w tym czasie aktem politycznym" ${ }^{\text {"45 }}$. Analogiczne czynniki motywacyjne wyboru nazwy widać w wypadku zakarpackiej drużyny piłkarskiej — S.K. Ruś (Użhorod), która wykorzystała w nominowaniu dawną nazwę Ukrainy — Ruś.

Nazwa ukraińskiego narodowego godła tryzu $b^{46}$, pełniącego za panowania Włodzimierza Wielkiego funkcję symbolu państwowego na Rusi, który stał się godłem Ukraińskiej Republiki Ludowej, symbolem ukraińskiego ruchu narodowo-wyzwoleńczego, odzwierciedlona jest w nominacji lwowskiego klubu piłkarskiego z dzielnicy Bogdanówka - U.S.K. Tryzub (Lwów).

Jedność (ścisły związek, spójność, integralność i niepodzielność ${ }^{47}$ ) ukraińskich regionów etnicznych, które na początku XX wieku należały do różnych państw, oraz marzenie ukraińskiego społeczeństwa o połączeniu tych obszarów w jednym państwie narodowym wyraża się w nazwie zespołu piłkarskiego z miasta Horodenka koło Iwano-Frankowska - S.K. Jednist (Horodenka).

Kalina $^{48}$ jako narodowy symbol Ukrainy stała się podstawą motywacyjną nazwy klubu piłkarskiego z miasteczka Żurawno rejonu żydaczowskiego w obwodzie lwowskim - S.K. Kalyna.

Wiele drużyn piłkarskich nosi różne nazwy, które jednak mogą być połączone w jedną grupę ze względu na semantykę rzeczownika ogólnego, z którego pochodzą. Wśród tych nominacji odnajdujemy wspólny sem wskazujący na pragnienie zwycięstwa, dążenie ku zwalczeniu trudności, zdobycie szczytu. Trzy zespoły wykorzystały w tytule rzeczownik pospolity probij, co oznacza 'przebicie dziury w czymś' ${ }^{\prime 9}$ : U.S.K. Probij (Horodenka), S.K. Probij (Złoczów), S.K. Probij (Pawełcze). Klub piłkarski S.T. Prołom (Stanisławów) otrzymał swoją nazwę od rzeczownika oznaczającego działanie, wskutek którego tworzy się dziura, luka, przerwa ${ }^{50}$; klub U.S.K. Peremoha (Nowy Jaryczów) — od rzeczownika peremoha 'zwycięstwo', którego jedno ze znaczeń to „sukces w walce o coś, uzyskanie czegoś wskutek walki, pokonania wszelkich trudności"51. Leksem rekord, "najwyż-

45 Спортове Товариство „Украӥна” (Львів), s. 57-58.

46 Великий тлумачний словник..., s. 1266.

47 Ibidem, s. 270.

48 Словник символів культури Украӥни, red. В.П. Коцура, О.І. Потапенка, М.К. Дмитренка, Київ 2002, s. 109-110.

49 Великий тлумачний словник..., s. 961.

50 Ibidem, s. 976.

51 Ibidem, s. 735. 
sze osiągnięcie, podjęte w czymś'52, był motywacją dla nazwy klubu sportowego z lwowskiej dzielnicy Kleparów - S.K. Rekord (Lwów). Inny zespół z tej samej dzielnicy Lwowa - S.K. Meta (Lwów) - wykorzystał do nazywania słowo meta, który ma znaczenie 'coś, do czego się dąży, czego chce się osiągnąć'53; wołyński zespół piłki nożnej U.S.K. Hart ze Zdołbunowa - rzeczownik pospolity hart 'wytrzymałość fizyczna i psychiczna człowieka'54.

Kilka nazw drużyn piłkarskich trudno połączyć w oddzielne grupy na podstawie wspólnych znaczeń, przykłady te warto jednak podać dla przedstawienia integralności korpusu nazw własnych ukraińskich klubów piłkarskich Galicji w pierwszej połowie XX wieku. Należą do nich: U.S.K. Watra (Drohobycz) — od dialektowego słowa watra — 'ognisko, ogień'55; S.T. Rusałka (Złoczów) od nazwy własnej pierwszego ukraińskiego almanachu „Rusałka Dniestrowa”, który ukazał się w roku 1848 w Budapeszcie staraniem pisarzy ukraińskich oraz działaczy publicznych Markijana Szaszkewycza, Jakowa Holowackoho oraz Iwana Wahylewycza; S.K. Striła (Kopyczyńce) — od słowa striła 'strzała — cienki pręt z ostrym zakończeniem lub ostrą końcówką, używany w łucznictwie ${ }^{56}$; U.S.K. Junak (Przemyślany) — od leksemu junak 'człowiek, który nie osiągnął jeszcze dojrzałości, młody mężczyzna'57.

Analiza materiału źródłowego pokazuje, że nazwy galicyjskich drużyn piłkarskich z pierwszej połowy XX wieku są złożonymi nominacjami, połączeniem skrótu i onimu. Abrewiatury nie różnią się zbytnio, na przykład: U.S.K. — Ukraiński Klub Sportowy, U.S.T. - Ukraińskie Towarzystwo Sportowe, S.K. - Klub Sportowy, S.T. - Towarzystwo Sportowe, U.R.S.K. - Ukraińskie Robotnicze Koło Sportowe i U.S.S.K. - Ukraiński Studencki Klub Sportowy, natomiast onimy reprezentują szeroką gamę nazw. Przeważają wyrazy pochodzenia ukraińskiego zarówno własne, jak i ogólne, które stały się podstawą motywacyjną do nominacji galicyjskich klubów piłkarskich. Wśród onimów zarejestrowano nazwy miast i małych miejscowości: Dobromyl, Dobriany, Kołomyja, Załuże, Pawełcze, Toporiwci, Czercze, Jamnycia oraz regionów Ukrainy: Łemkowszczyna, Podole, Podgórze; historycznie znaczące dla Ukraińców toponimy: Baturyn, Sicz Zaporoska, Sicz Czarnomorska, Chortycia; hydronimy: Dniepr, Dniestr, Zbrucz, San, Bystrzyca, Prut; oronimy: Beskid, Howerla, Łysonia, Czarnogóra i antroponimy: Bohun, Dowbusz, Karmeluk, Roksolana, Czernyk. Mniejszą grupę tworzą rzeczowniki ogólne: nazwy zjawisk naturalnych (huragan, burza, poświata, zamieć), nazwy topograficzne i nazwy obszarów naturalnych (urwiska, skały, step), nazwy ptaków (orzeł, sokół, czajka), nazwy symboli państwowych i narodowych

\footnotetext{
52 Ibidem, s. 1023.

53 Ibidem, s. 520.

54 Ibidem, s. 174.

55 Ibidem, s. 76.

56 Ibidem, s. 1205.

57 Ibidem, s. 1419.
} 
(trójząb, jedność, kalina) i inne. Najczęściej nominacje związane są z historią i kulturą Ukrainy, co jest dowodem na przemyślany dobór reprezentatywnych tytułów ukraińskich klubów piłkarskich.

\section{Bibliografia}

Andruhiv I., Ukraïns'ki molodižni tovaristva Galičini 1861-1939 rr., Ivano-Frankivs'k 1995.

Ânko M.P., Toponimičnij slovnik Ukraïni: Slovnik-dovidnik, Kiïv 1998.

Bobers'kij I., Zabavi i gri ruhovi, č. III. Kopanij mâč, L'viv 1906.

https://uk.wikipedia.org [elektronnij resurs].

Lavrivs'kij V., Kopana (Association Football), L'viv 1900.

Slovnik gidronimiv Ukraïni, red. A.P. Nepokupnij, O.S. Strižak, K.K. Cilujko, Kiïv 1979.

Slovnik simvoliv kul'turi Ukraïni, red. V.P. Kocura, O.I. Potapenka, M.K. Dmitrenka, Kiïv 2002.

Sportove Tovaristvo „Ukrä̈na” (L'viv). Do 80-riččâ zasnuvannâ: Al'manah, red. Kol. J. Los' et al., L'viv 1991.

Velikij tlumačnij slovnik sučasnoï ukraïns'koï movi, oprac. i red. V.T. Busel, Kï̈v-Irpin' 2001.

Verhola O., Kopanij mâč, L'viv 1926.

\section{Names of Ukrainian football clubs in Galicia in the first half of the 20th century}

\section{Summary}

In the article the author analyses the names of Ukrainian football clubs in Galicia in the first half of the 20th century from the point of view of their determinants. The sources encompass sports magazines functioning in Galicia in the inter-war period - in the 1920s and 1930s. The names of Galician football teams from the first half of the 20th century are combinations of abbreviations and onyms. The abbreviations do not differ considerably, but the onyms represent a broad range of names. The basic sources of names of Galician football clubs included names of towns: Dobromyl, Kolomyia, Zaluzhe, Pavlivka, Toporivci, and regions: Lemkivshchyna, Podolia in Ukraine; toponyms of historical significance to Ukrainians: Baturyn, Zaporozhian Sich; hydronyms: Dnieper, Dniester, Prut; oronyms: Beskid, Hoverla, and anthroponyms: Bohun, Dovbush, Karmeluk. A smaller group comprises general nouns: names of natural phenomena (hurricane, storm), topographical names and names of natural areas (cliff, rock, steppe), names of birds (eagle, falcon, lapwing) as well as names of state and national symbols (trident, unity, kalyna).

Keywords: chrematonymy, names of Galician clubs, sources of names 